Volume 2 Nomor 1, Februari 2017, halaman 11-28

\title{
KESULITAN-KESULITAN SISWA DALAM MEMPELAJARI MATEMATIKA PADA MATERI GARIS DAN SUDUT DI SMP N 4 SINDANG
}

\author{
Aan Juhana Senjaya1, Sudirman², Supriyatno ${ }^{3}$ \\ ${ }^{1}$ Universitas Wiralodra, Jalan Ir. H. Juanda KM.3 Singaraja Indramayu, \\ aansenjaya@yahoo.com \\ ${ }^{2}$ Universitas Wiralodra, Jalan Ir. H. Juanda KM.3 Singaraja Indramayu, \\ sudirmanunwir@gmail.com \\ ${ }^{3}$ Universitas Wiralodra, Jalan Ir. H. Juanda KM.3 Singaraja Indramayu, \\ supriyatno_pry@yahoo.com
}

\begin{abstract}
ABSTRAK
Penelitian ini bertujuan untuk mengetahui faktor penyebab kesulitan belajar matematika pada materi garis dan sudut di sekolah dan di rumah. Penelitian ini merupakan penelitian deskriptif kualitatif yang dilaksanakan di kelas VIIB, SMP N 4 Sindang. Analisis data yang digunakan dalam penelitian ini adalah teknik Bogdan dan Biklen untuk teknik analisis data. Penulis juga menggunakan triangulasi pengamat, tempat, waktu, dan teori untuk memeriksa keabsahan data yang didapatkan. Berdasarkan hasil penelitian dan kesimpulan yang diperoleh antara lain kesulitan siswa dalam mempelajari matematika pada materi garis dan sudut adalah (a) ketidakpahaman siswa terhadap soal yang ditentukan; (b) ketidakpahaman siswa terhadap konsep garis dan sudut; (c) ketidaktelitian siswa terhadap penulisan simbol (bahasa) matematika; (d) ketidaktelitian siswa pada perhitungan matematika. Adapun, Faktor-faktor yang menyebabkan kesulitan belajar sisiwa dalam mempelajari materi garis dan sudut terbagi menjadi dua, yaitu faktor intern dan ekstern. Faktor intern (dalam diri siswa) penyebab kesulitan belajar dalam mempelajari materi garis dan sudut yaitu tidak adanya minat siswa terhadap pembelajaran matematika dan cara/kebiasaan belajar siswa. Adapun, faktor ekstern (luar diri sisiwa) kesulitan belajar siswa dalam mempelajari matematika pada materi garis dan sudut SMPN 4 Sindang dilihat melalui 2 aspek yaitu faktor lingkungan sekolah dan lingkungan keluarga (rumah).
\end{abstract}

Kata Kunci: Kesulitan Belajar Siswa, Materi Garis dan Sudut
ABSTRACT
This study aims to determine the factors that cause difficulty learning mathematics in the material lines and angles at school and at home.This type of research is qualitative research. Subjects in this study were four students who have difficulty learning math class VIIB SMPN 4 Sindang. In this research, the writer used a technique Bogdan and Biklen'stechniqueto data analysis. The writer also uses triangulation observer, place, time, and theory to examine the validity of the data obtained. Based on the research results and conclusions obtained are students'difficulties in learning mathematics of the lines and anglesmaterial are (a) misunderstanding of the students toward a matter to be determined; $(b)$ ignorance of the students to the concept of lines and angles; (c) students to the inaccuracy of writing symbols (language) mathematics; (d) the inaccuracy of students on mathematical calculations. Meanwhile, the factors that cause students learning difficulties in learning lines and angles material is divided into two factors, namely the internal and external factors. Internal factors (in students) that caused learning difficulties in learning material lines and angles are the students are no interest towards learning mathematics and how/study habits of students. Meanwhile, extern factors (outside thestudents) students' learning difficulties in learning mathematics of the material lines and angles of SMPN 4 Sindang seen through two aspects, namely environmental factors of school and family environments (home).

Keywords: Students' Learning Difficulties, Lines and Angles Material. 
How to Cite: Senjaya, A. J., Sudirman, \& Supriyatno. (2017). Kesulitan-kesulitan Siswa dalam Mempelajari Matematika pada Materi Garis dan Sudut di SMPN 4 Sindang. Mathline: Jurnal Matematika dan Pendidikan Matematika, Vol.2, No.1, 11-28.

\section{PENDAHULUAN}

Pada prakteknya masih banyak peserta didik yang enggan untuk mempelajari matematika. Tidak sedikit peserta didik yang menganggap bahwa matematika adalah pelajaran yang sulit. Bahkan, pelajaran yang menakutkan bagi peserta didik sehingga seringkali mengakibatkan rendahnya hasil belajar matematika.Rendahnya hasil belajar tersebut merupakan salah satu indikator bahwa, siswa mengalami kesulitan belajar.

Kesulitan belajar tidak hanya dimiliki oleh siswa yang bersekolah di pedesaan namun juga dimiliki oleh siswa yang bersekolah di perkotaan. Hal tersebut sesuai dengan pendapat Djamarah (2011) yang menyatakan secara ringkas bahwa, kesulitan belajar tidak hanya dirasakan oleh sekolah modern di perkotaan, tapi juga dimiliki oleh sekolah tradisional di pedesaan dengan segala keminiman dan kesederhanaannya.Kesulitan belajar terjadi karena ketelitian, keterampilan, dan kecepatan dalam berpikir sangat diperlukan saat mempelajari matematika, tidak terkecuali pada materi garis dan sudut.Pada materi garis dan sudut siswa dituntut untuk bisa menghubungkan antar konsep, mengaplikasikan konsep, serta prinsip garis dan sudut. Sehingga, tidak aneh jika materi trigonometri merupakan materi yang sebagian besar dirasa sulit oleh siswa.Berdasarkan uraian di atas, Penelititertarik melakukan penelitian dengan judul "Kesulitan-Kesulitan Siswa dalam Mempelajari Materi Garis dan Sudut di SMP Negeri 4 Sindang”.Denganpenelitian ini diharapkan guru dapatmengetahui letak kesulitan serta faktor-faktor yangmenyebabkan siswa mengalami kesulitan saat mengerjakansoal garis dan sudut.

Fokus masalah dalam penelitian ini adalah (1) Kesulitan-kesulitan apa saja yang dialami siswa dalam mempelajari materi Garis dan Sudut?;(2) Faktor-faktor apa saja yang menyebabkan kesulitan belajar siswa dalam mempelajari materi Garis dan Sudut di rumah dan di sekolah?.Oleh karena itu tujuan dalam penelitian ini yakni untuk (1) Untuk mengetahui kesulitan-kesulitan apa saja yang dialami siswa dalam mempelajari materi Garis dan Sudut?;(2) Untuk faktor-faktor apa saja yang menyebabkan kesulitan belajar siswa dalam mempelajari materi Garis dan Sudut di rumah dan di sekolah. 


\section{METODE PENELITIAN}

Penelitian ini dilaksanakan di SMP Negeri 4 Sindang Indramayu Tahun Ajaran 2015/2016. Penelitian ini dilaksanakan pada semester genap tahun akademik 2015/2016. Metode yang digunakan dalam penelitian ini adalah metode deskriptif yangbertujuan untuk menggambarkan dan menganalisis letak kesalahan siswa dalam menyelesaikan persoalan garis dan sudut serta faktor-faktor yang dapat mempengaruhinya.Subjek yang dipilih sebanyak 4 siswa dari hasil tes terendah atau dibawah KKM yang telah ditentukan.

Untuk memperoleh data dalam penelitian ini, dilaksanakan pengumpulan data berdasarkan tahapan-tahapan: (1) pemberian tes, (2) observasi, (3) wawancara, (4) dokumentasi, (5) catatan lapangan. Analisis data yang digunakan berdasarkan argumen yang dikemukakan oleh Bogdan \& Biklen (Emzir, 2014), yakni: (a) Membuat keputusan yang mempersempit studi dengan mengubah pertanyaan; (b) memutuskan jenis pertanyaan yang akan dilaksanakan; (c) mengembangkan pertanyaan-pertanyaan analisis; (d) merencanakan sesi pengumpulan data; (e) membuat record sebanyak mungkin "komentar pengamat, key informan dan subjek" tentang ide-ide yang dihasilkan; (f) menulis catatan lapangan tentang peristiwa yang terjadi selama pengamatan; (g) mengujicobakan pertanyaan pada informan; (h) menjajagi sumber referensi sementara peneliti dilapangan; (i) Bermain dengan metafora, analogi, dan konsep-konsep; (j) Menggunakan perangkat visual.Pemeriksaan keabsahan data temuan dalam penelitian ini menggunakan teknik triangulasi., triangulasi merupakan keabsahan data untuk mengechek kebenaran data dari berbagai teknik dan sumber data.triangulasi yang digunakan dalam penelitian ini yaitu : (a) Triangulasi Pengamat; (b) triangulasi Tempat; (c) triangulasi waktu; (d) triangulasi teori.

\section{HASIL PENELITIAN DAN PEMBAHASAN}

Subjek penelitian dipilih sebanyak 4siswauntuk dilakukan penelitian lebih dalam guna mengetahui penyebab kesalahansiswa(subjek penelitian) dalam menyelesaikan soal materi garis dan sudut, serta untuk mengetahui faktor-faktor yang dapat menyebabkan siswa merasakan kesulitan dalam belajar. Adapun keempat subjek penelitian tersebut adalah Della, Erlina, Fauziah, dan Oky.

\section{Kesulitan-kesulitan yang dialami siswa dalam mempelajari materi Garis dan Sudut}


Berdasarkan Hasil tes subjek, pengamatan peneliti, kunci jawaban, serta wawancara yang telah dilakukan diperoleh data tentang kesulitan-kesulitan yang dialami siswa dalam menyelesaikan soal garis dan sudut yaitu: 1) Kesulitan prinsip operasi hitung, 2) kesulitan memahami konsep dan menghubungkan antar konsep materi sebelumnya, 3) ketidaktelitian subjek terhadap penulisan simbol matematika (bahasa matematika), 4) ketidakpahaman siswa terhadap soal yang ditentukan.

\section{Faktor-faktor yang menyebabkan kesulitan belajar siswa dalam mempelajari materi}

\section{Garis dan Sudut di rumah dan sekolah}

\section{a. Faktor-faktor penyebab kesulitan belajar siswa dalam mempelajari materi garis dan sudut dilihat dari faktor intern}

Berdasarkan hasil pengamatan serta wawancara, diperoleh hasil bahwa kesulitan belajar yang mungkin berasal dalam diri subjek adalah minat belajar siswa terhadap matematika yang kurang dan dan kebiasaan belajar siswa.

1) Minat Belajar Matematika yang kurang

Hasil pengamatan dan wawancara menunjukkan bahwa minat siswa yang mengalami kesulitan belajar matematika pada materi garis dan sudut tergolong rendah. Hal ini dapat dilihat dari tidak adanya ketertarikan siswa pada matematika. Berdasarkan wawancara tak terstruktur dengan siswa kelas VIIB, diperoleh informasi bahwa hanya tedapat 5 siswa yang menyukai matematika dari 40 siswa di kelas tersebut. Keempat subjek pada penelitian ini termasuk siswa yang tidak menyukai matematika. Hal tersebut diperkuat dengan pernyataan keempat subjek secara tertulis yang menyatakan secara ringkas bahwa subjek lebih tertarik dengan pelajaran selain matematika.

Adapun, menurut hasil pengamatan peneliti di rumah subjek yang secara ringkas menyatakan bahwa kedua subjek (Erlina dan Fauziah) menolak peneliti untuk memberikan pelajaran matematika tambahan di rumah masing-masing. Penolakan tersebut dikarenakan tidak adanya ketertarikan siswa terhadap matematika sehingga tidak ada gairah/motivasi untuk bersungguh-sungguh dalam mempelajari matematika. Hasil pengamatan juga diperkuat dengan hasil wawancara bersama subjek (Della) di rumahnya yang menyatakan secara ringkas bahwa subjek tidak menyukai matematika dengan alasan banyaknya perhitungan.

Tidak adanya minat atau ketertarikan siswa terhadap matematika akan menghambat siswa dalam belajar matematika sehingga mempengaruhi hasil belajar siswa. Hal tersebut sesuai dengan pendapat Dalyono yang dikutip oleh Djamarah (2011) yang secara inti 
menyatakan bahwa, minat belajar yang besar cenderung menghasilkan prestasi yang tinggi, sebaliknya minat belajar yang kurang akan menghasilkan prestasi yang rendah.

Tidak adanya minat belajar terhadap matematika juga didapatkan dari hasil pengamatan di sekolah, hasil pengamatan menunjukkan bahwa keempat subjek sering tidak memperhatikan penjelasan guru dengan seksama sehingga subjek tidak memahami materi yang telah dijelaskan oleh guru. Hal tersebut sesuai dengan pendapat Ahmadi \& Suprijono (2013) yang menyatakan bahwa, "Ada tidaknya minat terhadap sesuatu pelajaran dapat dilihat dari cara anak mengikuti pelajaran".

Hasil penelitian ini mendukung pendapat Ahmadi \& Suprijono (2013) yang secara ringkas menyatakan bahwa, faktor intern yang menjadi penyebab kesulitan belajar siswa salah satunya yaitu minat. Tidak adanya minat seorang siswa terhadap suatu pelajaran akan menimbulkan kesulitan belajar. Hasil penelitian ini juga mendukung pendapat Slameto (2013) yang secara ringkas menyatakan bahwa minat memiliki pengaruh besar terhadap belajar, karena bila bahan pelajaran yang dipelajari tidak sesuai dengan minat siswa, siswa tidak akan belajar dengan sebaik-baiknya karena tidak ada daya tarik baginya.

\section{2) Kebiasaan Belajar}

Berdasarkan pengamatan serta wawancara di sekolah dan rumah subjek. Peneliti memperoleh informasi bahwa keempat subjek memiliki kebiasaan belajar cenderung tidak baik. Mereka kurang memberikan keterlibatan dalam proses belajar mengajar di kelas. Berdasarkan pengamatan peneliti di rumah juga didapat informasi bahwa, keempat subjek memiliki kebiasaan belajar yang tidak teratur. Ketidakteraturan belajar dapat menghambat siswa untuk menguasai materi. Hal tersebut sesuai dengan pendapat Djamarah (2002) yang secara ringkas mengemukakan bahwa salah satu faktor yang dapat mengakibatkan kegagalan siswa dalam mencapai prestasi belajar adalah ketidakteraturan dalam belajar. Ketidakteraturan dalam belajar ini diungkapkan oleh Ibu Pratiwi selaku orang tua subjek (Fauziah) yang secara ringkas mengungkapkan bahwa, waktu belajar subjek di rumah hanya ketika mendapat PR dari sekolah. Namun, ketika menjelang ulangan semester justru subjek tidak belajar. Ketidakteraturan dalam belajar ini diungkapkan oleh ibu Titi selaku orang tua subjek (Oky) yang secara ringkas mengungkapkan bahwa, waktu belajar subjek tidak teratur. Subjek belajar ketika disuruh dan ditemani oleh ibunya, ketika ada PR dan ulangan. Ibu Titi juga menambahkan bahwa, ketika ibu tidak dapat menemani subjek belajar maka subjek juga tidak belajar. Berdasarkan wawancara, ketidakteraturan dalam belajar ini diungkapkan oleh ibu Karsini selaku nenek subjek (Della) yang secara ringkas 
mengungkapkan bahwa, subjek jarang terlihat belajar. Adapula subjek yang tidak pernah belajar di rumahnya, seperti yang di ungkapkan orang tuanya yang bernama Bapak Rasdi. Menurut Bapak Rasdi secara ringkas mengemukakan bahwa, subjek tidak pernah belajar dirumah. Bahkan, kegiatan setiap harinya kebanyakan hanya menonton TV. Berdasarkan pengamatan disekolah juga didapat bahwa subjek (Erlina) tergolong siswa dengan kehadiran yang kurang baik.

Berdasarkan paparan diatas maka kebiasaan belajar siswa yang buruk dapat menghambat perkembangan belajar siswa. Oleh karena itu, kebiasaan belajar dapat menjadi faktor kesulitan siswa dalam mempelajari matematika khususnya garis dan sudut. Hasil penelitian peneliti tersebut sejalan dengan hasil penelitian Haryatni (2014) dengan judul penelitian "Identifikasi Faktor-faktor Penyebab Kesulitan Belajar pada Siswa SMP Negeri 5 Kota Jambi”. Dalam penelitiannya, menyimpulkan bahwa salah satu faktor penyebab kesulitan belajar siswa dikarenakan faktor emosi dan kebiasaan yang salah meliputi malas belajar, kurang berminat, sering bolos, dan aktifitas yang kurang menunjang.

\section{b) Faktor-faktor yang menyebabkan kesulitan belajar siswa dalam mempelajari materi Garis dan Sudut dilihat dari faktor Eksternal}

Faktor eksternal yang menyebabkan kesulitan belajar, khususnya mata pelajaran matematika pada materi garis dan sudut yang dialami siswa terdiri dari beberapa sub aspek, yaitu sub aspek faktor lingkungan sekolah dan keluarga.

\section{Faktor Lingkungan Sekolah}

Berdasarkan hasil pengamatan serta wawancara, diperoleh hasil bahwa kesulitan belajar siswa dalam mempelajari materi garis dan sudut yang disebabkan karena pengaruh lingkungan sekolah adalah sebagai berikut.

1) Waktu Pembelajaran

Hasil pengamatan dan wawancara menunjukkan bahwa waktu pembelajaran matematika yang dilaksanakan di sekolah tidak efektif/kondusif karena alokasi waktu yang tidak tepat. Berdasarkan hasil pengamatandiperoleh informasi bahwa penjadwalan pembelajaran matematika yang ditetapkan oleh sekolah pada kelas VII B adalah 2hari/minggu pada siang hari. Berdasarkan pengamatan peneliti. diperoleh hasil bahwa waktu pembelajaran yang diterapkan pada kelas tersebut nampak tidak efektif/kondusif dikarenakan pembelajaran seringkali terpotong jeda waktu istirahat. Sehingga, konsentrasi belajar siswa pun terganggu. Berdasarkan pengamatan tersebut juga diperoleh hasil bahwa 
kondisi siswa yang sudah melemah dan lelah nampaknya tidak dapat menerima pelajaran secara optimal. hasil pengamatan tersebut diperkuat oleh pernyataan Ibu Lika selaku guru matematika melalui wawancara tak terstruktur yang secara ringkas menyatakan bahwa, waktu pembelajaran yang diterapkan siang hari mempengaruhi proses belajar siswa, tak jarang siswa mendengarkan penjelasan sembari mengantuk. Ibu Lika juga menambahkan pendapatnya melalui wawancara dengan waktu yang berbeda, ia mengungkapkan bahwa waktu dipagi hari lebih efektif dibandingkan siang hari karena kondisi siswa dan guru masih dalam keadaan segar.

Hasil penelitian mendukung pendapat Djamarah (2011) yang secara inti menyatakan bahwa kondisi siswa tidak lagi dalam keadaan yang optimal untuk menerima pelajaran apabila dilaksanakan siang atau sore hari. Oleh karena itu, belajar dipagi hari akan lebih baik hasilnya daripada belajar disiang atau sore hari. Berdasarkan hasil pengamatan dan kedua pendapat tersebut, maka waktu pembelajaran matematika disiang hari mungkin dapat menjadi salah satu faktor siswa mengalami kesulitan belajar padamateri garis dan sudut. Selain itu, hasil penelitian ini juga mendukung pendapat Slameto (2013) yang menyatakan secara ringkas bahwa, memilih waktu sekolah yang tepat akan memberi pengaruh yang positif terhadap belajar. Waktu yang baik untuk belajar adalah di pagi hari saat jasmani dalam kondisi yang baik. Jika siswa belajar pada waktu kondisi badannya sudah mulai melemah/lelah, siswa akan mengalami kesulitan di dalam menerima pelajaran.

\section{2) Media Pembelajaran}

Berdasarkan pengamatan penelitipada saat pembelajaran matematika berlangsung, diperoleh hasil bahwa guru tidak pernah menggunakan media dalam pembelajaran matematika.Padahal keberadaan media dapat membantu menutupi kekurangan yang dimiliki oleh guru. Oleh karena itu, ketiadaan media memungkinkandapat membuat siswa merasa jenuh dan mengurangi semangat belajar siswa. Seperti halnya pernyataan Oky melalui wawancara tak terstrukturyang menyatakan secara ringkas bahwa subjek merasa tidak dapat mendengar dengan jelas penjelasan dari guru. Sehingga, subjek lebih memilih fokus pada pekerjaannya sendiri dibandingkan memperhatikan gurunya. Adapun pernyataan Ibu Lika selaku guru matematika melalui wawancarasecara ringkas menyatakan bahwa beliau memang tidak pernah menggunakan media saat pembelajaran matematika dikelas dengan alasan keterbatasan media yang dimiliki sekolah.

Hasil penelitian ini mendukung pendapat Ahmadi (2009) yang pada intinya mengemukakan bahwa, lingkungan sekolah terkadang dapat menjadi faktor hambatan bagi 
anak. Termasuk dalam faktor ini adalah alat-alat belajar di sekolah yang serba tidak lengkap. Alat-alat tersebut juga meliputi alat peraga dan media pembelajaran matematika.Hasil penelitian peneliti juga mendukung pendapat Djamarah (2011) yang secara ringkas menyatakan bahwa, beberapa faktor-faktor di lingkungan sekolah yang dapat menimbulkan siswa berkesulitan belajar salahsatunya adalah alat/media yang kurang memadai. Alat pelajaran yang kurang lengkap membuat penyajian pelajaran yang tidak baik.

\section{3) Metode Pembelajaran}

Berdasarkan hasil pengamatan peneliti disekolah, cara mengajar guru matematika kelas VII B di SMPN 4 Sindang terbilang monoton. Cara guru membuka pembelajaran tanpa diawali dengan pemberian motivasi, tujuan pembelajaran, dan tanpa mengecek kehadiran siswa. Guru juga tidak memberikan kesimpulan dalam setiap akhir pembelajaran. Strategi pembelajaran yang diterapkan dalam pembelajaran matematika di kelas memperlihatkan bahwa strategi pembelajaran yang digunakan adalah strategi yang berpusat pada guru. Berdasarkan pengamatan peneliti diperoleh informasi bahwa strategi yang diterapkan oleh guru dikategorikan sebagai strategi pembelajaran ekspositori. Strategi ini direalisasikan oleh guru dengan menggunaan metode ceramah.

Berdasarkan pengamatan peneliti di sekolah, diperoleh bahwa pada pembelajaran matematika, metode pembelajaran yang digunakan guru pada saat pembelajaran matematika didominasi oleh metode ceramah. Hasil observasi tersebut dibenarkan oleh guru yang bersangkutan melalui wawancarayang menyatakan secara ringkas bahwa guru yang bersangkutan hanya menggunakan metode ceramah dengan alasan waktu yang tidak memungkinkan untuk menggunakan metode yang lain.

Hasil observasi dan wawancara di atas dapat menyebabkan kesempatan siswa untuk berbicara sangat terbatas dan kesempatan tersebut tidak dapat dimanfaatkan secara maksimal. Penggunaan metode ceramah pada pembelajaran dapat menjadi salah satu faktor penyebab kesulitan belajar siswa dalam pembelajaran garis dan sudut. Hasil penelitian tersebut senada dengan pendapat Djamarah \& Zain (2002) yang menyatakan secara ringkas bahwa penggunaan metode ceramah dengan tujuan pembelajaran agar siswa mampu memperagakan sesuatu, dalam hal ini mampu menyelesaikan permasalahan garis dan sudut, kurang tepat digunakan karena hanya akan tercipta pembelajaran yang kurang kondusif (kurang efektif dan efisien). 
4) Hubungan guru Matematika dengan siswa yang mengalami kesulitan belajar pada Matematika

Berdasarkan hasil pengamatan menunjukkan bahwa hubungan antara guru dengan siswaterkesan kurang harmonis sehingga siswa mengalami kesulitan belajar.Hal tersebut dapat dibuktikan dengan tidak adanya interaksi antara guru dengan siswa berkesulitan belajar pada saat pembelajaran maupun diluar. Pada pengamatan tersebut juga didapat informasi bahwa jenis komunikasi yang mendominasi pembelajaran adalah komunikasi satu arah sehingga terkesan siswa hanya sebagai pendengar setia. Komunikasi seperti itu memungkinkan hubungan antar guru dengan siswa. Bahkan, siswa dengan siswa terkesan tidak hidup sehingga dirasa bosan oleh siswa.

Rasa bosan bagi peserta didik bisa saja menimbulkan kurangnya motivasi mereka untuk belajar dan memperhatikan guru saat pembelajaran. Sesekali sang guru melakukan interaksi dengan beberapa siswa. Namun, tidak dengan keempat subjek dalam penelitian ini. Hasil pengamatan tersebut diperkuat dengan pernyataan guru matematika melalui wawancara yang menyatakan secara ringkas bahwa guru tidak pernah melakukan interaksi dalam bentuk tanya jawab karena subjek sangatlah pendiam. Hasil pengamatan juga diperkuat dengan pengakuan Della (subjek penelitian) melalui wawancara tak terstruktur di rumahnya yang secara ringkas menyatakan bahwa ketika subjek menemukan kesulitan dalam mempelajari materi garis dan sudut, subjek lebih memilih bertanya kepada teman sebangku dibanding bertanya kepada guru yang bersangkutan dengan alasan malu. Adapula, pernyataan Oky (subjek penelitian) melalui wawancara tak terstruktur di rumahnya yang secara ringkas menyatakan bahwa ketika materi yang disampaikan tidak dimengerti oleh subjek.Maka, subjek lebih sering bertanya kepada teman daripada kepada guru yang bersangkutan.

Hasil penelitianpeneliti yang menyatakan bahwa hubungan antar guru dengan siswa yang kurang harmonis dapat menjadi faktor dari kesulitan belajar siswa, mendukung pendapat Ahmadi (2009) yang secara ringkas menyatakan bahwa, beberapa faktor-faktor di lingkungan sekolah yang dapat menimbulkan siswa berkesulitan belajar adalah hubungan guru dan murid yang kurang baik.

Selain itu, hasil penelitian yang menyatakan bahwa hubungan/interaksi antar guru dengan siswa yang kurang harmonis dapat menjadi salah satu faktor siswa berkesulitan dalam mempelajari matematika pada materi garis dan sudut, juga mendukung pendapat Slameto (2013) yang secara ringkas menyatakan bahwa ada beberapa faktor sekolah yang 
dapat menyebabkan siswa mengalami kesulitan belajar. Faktor tersebut salah satunya mencakup tentang relasi guru dengan siswa. Guru yang kurang berkinteraksi dengan siswa secara akrab dapat menyebabkan proses pembelajaran kurang lancar. Siswa juga akan merasa jauh dari guru, hingga mengakibatkan siswa segan untuk berpartisipasi secara aktif dan belajar.

\section{5) Hubungan antar siswa dengan siswa}

Berdasarkan hasil pengamatan diperoleh hasil bahwa terdapat dua subjek yang memiliki sifat pendiam dan pemalu. Berdasarkan pengamatan peneliti di sekolah diperoleh informasi bahwa Della dan Fauziah merupakan siswa yang tidak bisa berbaur dengan mudah seperti teman-temannya yang lain. Hal tersebut terlihat dari tidak nampaknya interaksi antar subjek dengan siswa lain. Hasil pengamatan peneliti juga menyatakan bahwa ketika subjek menemukan kesulitan pada materi yang dipelajari, subjek lebih memilih diam daripada harus bertanya pada guru yang bersangkutan atau teman yang memahami materi tersebut, terkecuali teman sebangku.

Hasil pengamatan diperkuat oleh pernyataan teman kelasnya yaitu Septi melalui wawancara yang menyatakan secara ringkas bahwa meskipun tempat duduk antara Septi dan kedua subjek berdampingan, kedua subjek tersebut tidak pernah menanyakan materi yang tidak dimengerti oleh mereka. Hasil pengamatan juga diperkuat oleh pernyataan Sultan yang menyatakan secara inti bahwa kedua subjek tersebut memang hampir tidak pernah berbaur dengan teman-temannya yang lain.Selain itu, hasil penelitian juga diperkuat oleh pernyataan Ibu Hernawati selaku wali kelas VII B melalui wawancara yang secara ringkas menyatakan bahwa kedua subjek tersebut (Della dan Fauziah) adalah siswa yang paling pendiam diantara siswa yang lain. Ibu Ernawati juga menambahkan bahwa mereka adalah siswa yang tidak memiliki percaya diri yang tinggi untuk berbicara dengan orang lain termasuk teman-temannya.Berdasarkan paparan di atas maka hubungan antara siswa dengan siswa adalah penyebab subjek penelitian mengalami kesulitan belajar matematika pada materi garis dan sudut. Hubungan baik antar siswa dengan siswa akan menciptakan suasana yang baik, seperti mudahnya bertanya tentang materi yang dianggap sulit. Oleh karena itu, menciptakan hubungan baik antar siswa akan membantu/mempermudah proses belajar. Hal tersebut sesuai dengan pendapat Slameto (2013) yang menyatakan bahwa, "menciptakan relasi yang baik antar siswa adalah perlu, agar dapat memberikan pengaruh yang positif terhadap belajar siswa." 
Hasil penelitian ini sejalan dengan hasil penelitian Dewantara (2012) dengan judul, "Identifikasi Faktor Penyebab Kesulitan Belajar Keterampilan Berbicara Siswa Kelas VIIE SMPN 5 Negara dan Strategi Guru untuk mengatasinya". Hasil penelitian ini menyatakan bahwa faktor-faktor yang berpengaruh terhadap kesulitan belajar siswa dalam pembelajaran keterampilan berbicara salah satunya adalah hubungan/interaksi antar siswa dengan siswa masih rendah. Sikap siswa yang demikian berdampak terhadap hasil belajar siswa. Kesesuaian dari penelitian di atas adalah adanya pengaruh hubungan/interaksi antar siswa dengan siswa yang masih rendah terhadap kesulitan belajar siswa SMP kelas VII. Matematika merupakan salah satu pelajaran untuk SMP kelas VII sehingga hubungan/interaksi antar siswa juga dapat mempengaruhikesulitan belajar siswa.

6) Keaktifan Berorganisasi yang berlebihan.

Berdasarkan hasil pengamatan diperoleh hasil bahwa subjek mengikuti kegiatan Organisasi secara berlebihan. Berdasarkan pengamatan peneliti diperoleh informasi bahwa Oky termasuk siswa yang berprestasi pada beberapa organisasi seperti Karate dan Pramuka. Subjek tergolong sisiwa yang aktif dalam kegiatan Ekstrakulikuler/Organisasi secara berlebihan. Hal tersebut menyebabkan subjek tidak memiliki waktu belajar pada siang hari dan juga subjek merasa lelah pada malam hari, sehingga subjek lebih memilih istirahat dibandingkan belajar ataupun mengulang materi yang telah dipelajarinya disekolah. Hal tersebut dibenarkan oleh Ibu Tuti selaku orang tuanya, yang menyatakan secara ringkas bahwa subjek seringkali tidak menyempatkan diri untuk belajar pada waktu siang hari karena kesibukan organisasinya. Subjek juga seringkali tertidur lelap pada malam hari tanpa menyempatkan untuk belajar atau mengulas materi yang telah dipelajarinya.

Berdasarkan hasil temuan di atas, maka peneliti beranggapan bahwa kegiatan organisasi/ekstrakulikuler yang berlebihan akan mengganggu belajar subjek sehingga akan mengalami kesulitan-kesulitan dalam belajar. Dalam hal ini dalam mempelajari matematika pada materi garis dan sudut. Namun, persepsi peneliti bertentangan dengan salah satu guru bahasa inggris disekolah tersebut. Pak Dadang selaku guru bahasa inggris yang merangkap sebagai Pembina karate menyatakan secara ringkas bahwa subjek tidak mungkin mengalami kesulitan belajar karena subjek adalah siswa yang berprestasi dibidang karatenya. Oleh karena itu, tidak mungkin seorang juara itu bodoh, ungkapnya. Ketidaksesuaian tersebut kemungkinan besar dikarenakan guru tersebut tidak mengetahui keaktifan subjek pada organisasi lain serta keadaan subjek di rumahnya. Berdasarkan 
pengamatan diperoleh informasi, Ibu Herna selaku Walikelas pun menyatakan bahwa siswa memang diharapkan untuk aktif pada organisasi namun tidak untuk menyampingkan urusan belajar ataupun menjalani kegitan Ekstrakulikuler secara berlebihan karena akan menggangu perkembangan belajar siswa. Hal tersebut senada dengan pendapat Ahmadi (2009) yang secara ringkas menyatakan bahwa yang menjadi salah satu penyebab anak berkesulitan belajar adalah adanya kegiatan-kegiatan dalam masyarakat. Seperti ikutserta dalam berorganisasi, belajar pencat silat dan menari. Jika kegiatan ini dilebih-lebihkan jelas akan menghambat belajar anak.

\section{Faktor Lingkungan Keluarga}

1) Latar pendidikan orangtua

Pendidikan terakhir orang tua menurut peneliti bisa saja berpotensi sebagai penyebab siswa berkesulitan belajar. Orang tua berpendidikan tinggi mempunyai pengetahuan lebih luas dibandingkan dengan orangtua yang berpendidikan rendah. Ilmu pengetahuan (Matematika) yang dipelajari siswa disekolah mungkin tidak didapat oleh orang tua pada saat bersekolah dulu. Oleh karena itu, ketika siswa menemukan kesulitan belajar pada matematika maka orang tua tidak dapat membantu anak-anaknya. Seperti yang dikatakan oleh Ibu Titi selaku orangtua subjek melalui wawancara yang secara ringkas menyatakan bahwa ia hanya bisa mendampingi belajar tanpa bisa membantu anaknya menyelesaikan tugas ataupun memberi pemahaman tentang materi yang tidak dimengerti oleh anak. Hal tersebut juga dirasakan oleh Ibu Karsinih selaku nenek subjek (Della) yang secara ringkas menyatakan bahwa orang tua dari subjek tidak pernah mau mengajari anaknya tanpa alasan. Namun, setelah peneliti mewawancarai Ibu Lilisselaku orang tua subjek diperoleh informasi bahwa beliau tidak mau mengajari sang anak karena tidak mengerti tentang materi yang sedang dipelajari anaknya. Orangtua yang memiliki pendidikan yang cukup memadai akan memberikan perhatian dan arahan terhadap pendidikan anaknya. Anak akan merasa bingung, ketika orang tua tidak dapat mengarahkannya. Seperti yang dikatakan oleh kedua subjek pada pengamatan peneliti, siswa berkesulitan belajar menyatakan bahwa siswa tidak bisa bertanya kepada orang tua dan keluarga di rumah tentang materi yang tidak dimengerti.

Hasil penelitian ini sejalan dengan hasil penelitian Sakdiyah (2011), dengan judul, "Pengaruh Tingkat Pendidikan Orang Tua Terhadap Prestasi Belajar Anak Di sekolah (Studi Pada Kelas VIII di Madrasah Tsanawiyah Negeri Klego Kabupaten Boyolali Tahun 2011/2012". Hasil penelitian tersebut menunjukan bahwa terdapat pengaruh yang 
signifikan pendidikan orang tua terhadap prestasi anak di MTs Negeri Klego tahun pelajaran 2011/2012. Selain itu, hasil penelitian Mulianto (2011) dengan judul "Kesulitan Belajar (Learning Difficulty) Siswa SMA di Pedalaman Papua”.Menyimpulkan bahwa, faktor eksternal yang menjadi penyebab kesulitan belajar di sekolah tersebut adalah faktor keluarga yang salah satunya meliputi latar pendidikan orang tua.Hasil penelitian peneliti yang menyatakan bahwa latar belakang pendidikan orang tua siswa dapat mempengaruhi kesulitan belajar siswa,juga sejalan dengan hasil penelitian Dasmo, dkk (2012), dengan judul "Pengaruh Tingkat Pendidikan dan Pola Asuh Orang Tua Terhadap Prestasi Belajar IPA". Hasil penelitian tersebut menunjukan bahwa terdapat pengaruh tingkat pendidikan orang tua terhadap prestasi belajar IPA siswa. Semakin tinggi tingkat pendidikan orang tua diikuti oleh prestasi belajar IPA siswa.

\section{2) Perhatian Orang Tua}

Hasil pengamatan menunjukkan bahwa orang tua siswa yang mengalami kesulitan belajar matematika tergolong kurang memperhatikan kegiatan belajar anaknya di rumah. Seperti halnya yang dikatakan ibu Titi selaku ibu dari subjek (Oky) yang secara ringkas menyatakan bahwa ayah subjek tidak pernah menyuruh anaknya untuk belajar karena sifatnya yang acuh.Keacuhan orang tua terhadap pendidikan anak juga dialami oleh orangtua subjek (Della).Menurut ibu Karsinih selaku nenek dari subjek (Della) secara ringkas menyatakan bahwa ibu dari subjek tidak pernah memperhatikan belajar anaknya karena berbeda tempat tinggal.Ibu Karsinih juga menambahkan bahwa, ayah tiri subjek tidak pernah berinteraksi dengan subjek.Oleh karena itu, ayah tiri subjek pun tidak pernah memperhatikan belajar subjek di rumah. Berdasarkan pengamatan lain, Ibu karsinih menyatakan bahwa ayah kandung subjek pun tidak pernah menjenguk anaknya dan tidak memperhatikan fasilitas pendidikan anaknya. Berdasarkan hasil wawancara dengan bapak Tanjan selaku ayah dari Oky menyatakan secara ringkas bahwa beliau tidak tahu mengenai aktifitas belajar anaknya di rumah karena waktu pekerjaan yang tidak menentu.

Adapun, hasil wawancara bersama subjek (Della) diperoleh bahwa sejak pamannya tidak lagi tinggal bersama subjek, tidak ada lagi yang memperhatikan belajarnya di rumah serta tidak ada lagi yang memeriksa hasil belajarnya di sekolah.Adapula, hasil wawancara bersama subjek (Oky) yang secara ringkas menyatakan bahwa, subjek tidak pernah diperintahkan atau ditemani belajar oleh ayahnya.Orang tua yang tidak memberikan perhatian lebih terhadap belajar anaknya, mengakibatkan siswa yang mengalami kesulitan belajar matematika merasa malas karena tidak adanya dorongan atau motivasi dari orang 
tua. Tidak adanya perhatian dari orang tua juga mungkin dapat mengakibatkan kebiasaan belajar siswa yang buruk dan tidak teratur seperti; belajar ketika ada PR saja, belajar ketika akan dilaksanakan ulangan, bahkan tidak pernah belajar. Hal demikian memungkinkan siswa akan mengalami kesulitan belajar Matematika baik di rumah maupun di sekolah. Hal tersebut sesuai dengan pendapat Djamarah \& Zain (2002) yang mengemukakan secara ringkas bahwa salah satu faktor yang mengakibatkan kegagalan siswa dalam mencapai prestasi belajar adalah ketidakteraturan dalam belajar.Hasil penelitian juga mendukung pendapat Ahmadi (2009) secara inti menyatakan bahwa faktor orang tua merupakan faktor yang besar pengaruhnya terhadap kemajuan belajar siswa. Orang tua yang tidak mengindahkan pendidikan anak-anaknya, acuh tak acuh, bahkan tidak memperhatikan sama sekali tentu tidak akan berhasil dalam belajarnya.

3) Keadaan ekonomi keluarga

Berdasarkan hasil pengamatan juga diperoleh bahwa keadaan ekonomi keluarga atau orang tua siswa tergolong rendah. Menurut pengamatan peneliti diperoleh informasi, bahwa orangtua subjek (Oky) tidak memiliki rumah pribadi yang membuat mereka bebas melakukan apapun. Berdasarkan pengamatan peneliti juga diperoleh, bahwa hampir setiap ada kebutuhan sekolah yang mendadak subjek harus memenuhinya sendiri tanpa meminta kepada orang tua. Subjek seringkali menyisihkan uang jajannya. Bahkan, ketika berangkat dan pulang sekolah subjek lebih memilih berjalan kaki daripada harus mengeluarkan uang untuk naik kendaraan umum. Uang saku yang seharusnya digunakan transport sekolah justru subjek gunakan untuk memenuhi kebutuhan sekolahnya. Ibu Titi selaku orang tua subjek (Oky) juga menambahkan bahwa, Orangtua subjek hanya bisa membelikan anaknya buku LKS (buku lembar siswa) yang diwajibkan sekolah. Namun, tidak dapat membelikan anaknya buku paket atau lainnya. Berdasarkan paparan tersebut nampaknya kondisi ekonomi keluarga yang rendah dapat menjadi penghambat subjek dalam belajar. Oleh karena itu, kondisi ekonomi keluarga dapat menjadi penyebab/faktor siswa mengalami kesulitan dalam belajar.

Hasil penelitian ini mendukung pendapat Ahmadi \& Suprijono (2013) yang secara ringkas menyatakan bahwa keadaan ekonomi keluarga merupakan faktor kesulitan belajar siswa. keadaan ekonomi yang kurang/miskin akan menimbulkan kurangnya alat-alat belajar, kurangnya biaya yang disediakan oleh orang tua, dan tidak mempunyai tempat belajar yang baik.Hasil penelitian peneliti juga sejalan dengan hasil penelitian Cahyo $\mathrm{S}$ (2010), dengan judul penelitian, "Faktor-faktor yang Mempengaruhi Prestasi Belajar 
Kewirausahaan Siswa Kelas XI SMKN 1 Punggelan Banjanegara”. Hasil dari penelitian tersebut menunjukan bahwa faktor lingkungan keluarga merupakan salah satu faktor yang mempunyai pengaruh cukup besar terhadap perkembangan siswa. Adapun, salah satu indikatornya yaitu keadaan ekonomi keluarga. Semakin baik kondisi ekonomi keluarga siswa maka prestasi belajar siswa akan semakin baik, sebaliknya semakin rendah atau kurang baik kondisi ekonomi keluarga maka prestasi belajarnya semakin rendah.

4) Suasana Rumah

Berdasarkan hasil pengamatan diperoleh hasil bahwa suasana rumah dari kedua subjek nampak tidak mendukung kenyamanan dan ketenangan siswa dalam belajar. Berdasakan pengamatan peneliti selama di rumah subjek (Della), nampak suasana belajar selalu dilengkapi dengan teriakan anak-anak. Anak-anak tersebut yaitu ketiga adik subjek, terkadang nampak mereka mengganggu ketika subjek sedang belajar bersama peneliti. Hal tersebut diperkuat oleh pernyataan Subjek dan juga Susi selaku Bibi dari subjek yang masih duduk di sekolah menengah pertama kelas VIII, melalui wawancara mereka menyatakan secara ringkas bahwa, seringkali subjek diganggu oleh adiknya ketika belajar. Berdasarkan hal tersebut, nampaknya subjek merasakan ketidaknyamanan belajar dirumah dikarenakan adanya gangguan yang berasal dari adik-adik kecilnya. Hal tersebut diperkuat oleh pernyataan Ibu Karsinih selaku nenek subjek yang menyatakan secara ringkas bahwa, terkadang anak-anak (adik subjek) setiap malam selalu bermain bersama dan tak jarang mereka berteriak-teriak hingga larut malam. Keadaan yang digambarkan nenek subjek tentu akan mengganggu konsentrasi dan kenyamanan subjek jika belajar di malam hari.

Berdasarkan pengamatan peneliti diperoleh bahwa subjek memiliki dua tempat tinggal berbeda. Kedua tempat tinggal tersebut bukanlah hak milik dari kedua orang tuanya. Berdasarkan pengamatan diperoleh bahwa suasana belajar di tempat tinggal pertama, tempat belajar bersama peneliti dan subjek. Nampaknya, suasana belajar sedikit nyaman meski masih dilengkapi dengan gaduhnya suara obrolan-obrolan dari pihak saudara subjek dan minimnya cahaya. Berdasarkan hasil wawancara dengan Ibu Titi dan subjek,diperoleh bahwa tempat tinggal yang kedua terkesan menyeramkan karena pintu rumah subjek berhadapan langsung dengan makam salah satu buyut Indramayu. Suasana tersebut membuat subjek merasa takut ketika belajar, sehingga subjek tidak dapat berkonsentrasi.Hal tersebut dibenarkan oleh subjek (Oky) melalui wawancara yang menyatakan bahwa, subjek merasa ketakutan ketika belajar di rumah tanpa ditemani oleh orang tua.Pernyataan ibu Titi dan subjek (Oky) diperkuat dengan pengamatan langsung 
oleh peneliti, diperoleh informasi bahwaletak pintu rumah tersebut memang benar berhadapan dengan makam buyut paoman. Adapun, ibu Titi menambahkan bahwa pemukiman yang kini mereka tinggali adalah bekas tanah kuburan yang sudah dipindahkan. Hal demikian membuat subjek merasa parno setiap kali belajar sendirian, sehingga subjek tidak bisa berkonsentrasi.

Tempat yang biasa digunakan subjek untuk belajar adalah ruang televisi yang terletak tak jauh dari pintu masuk. Bukan hanya menyeramkan, melainkan suasana belajar dirumah tersebut tidak nyaman karena terdapat bau tak enak yang berasal dari salahsatu kamar mbahnya yang terbujur sakit. Berdasarkan hal tersebut, nampaknya subjek mengalami kesulitan belajar yang besar kemungkinan disebabkan oleh ketidaknyamanan suasana belajar yang telah disebutkan di atas. Kesulitan belajar yang dipengaruhi oleh suasana rumah juga diungkapkan oleh ibu Hernawati selaku walikelas sekaligus tetangga subjek yang menyatakan secara ringkas bahwa, kegagalan siswa dalam belajar didominasi oleh suasana tempat belajar yang tidak mendukung.

Berdasarkan beberapa paparan diatas, maka peneliti beranggapan bahwa suasana belajar siswa di rumah dapat menjadi salah satu faktor kegagalan/kesulitan siswa dalam belajar matematika khususnya materi garis dan sudut. Hasil penelitian ini mendukung pendapat Ahmadi \& Suprijono (2013) yang secara ringkas menyatakan bahwa anak tidakmungkin dapat belajar dengan baik ketika suasana keluarga sangat ramai/gaduh, demikian juga dengan suasana rumah yang selalu tegang. Hasil penelitian inijuga sejalan dengan hasil penelitian Cahyo S(2010), dengan judul penelitian "Faktor-faktor yang Mempengaruhi Prestasi Belajar Kewirausahaan Siswa Kelas XI SMKN 1 Punggelan Banjanegara". Hasil dari penelitian tersebut menunjukan bahwa faktor lingkungan keluarga merupakan salah satu faktor yang mempunyai pengaruh cukup besar terhadap perkembangan siswa. Adapun, salah satu indikatornya yaitu suasana rumah/keluarga. Semakin baik suasana rumah siswa maka prestasi belajar siswa akan semakin baik, sebaliknya semakin rendah atau kurang baik suasana rumah maka prestasi belajar semakin rendah.

\section{KESIMPULAN}

Berdasarkan hasil penelitian yang dilakukan di kelas VII B SMPN 4 Sindang dan pembahasan yang telah disampaikan pada bagian sebelumnya maka peneliti 
mempersepsikan sebagai berikut. (1) Kesulitan-kesulitan yang dialami siswa dalam mempelajari materi garis dan sudut yaitu: (a) Ketidakpahaman siswa terhadap soal yang ditentukan; (b) Ketidakpahaman subjek terhadap konsep garis dan sudut; (c) Ketidaktelitian subjek terhadap penulisan simbol (bahasa) matematika; (d) Ketidaktelitian siswa pada perhitungan matematika. (2) Faktor-faktor yang menyebabkan kesulitan belajar sisiwa dalam mempelajari materi garis dan sudut terbagi menjadi dua, yaitu faktor intern dan ekstern. Faktor intern (dalam diri siswa) penyebab kesulitan belajar dalam mempelajari materi garis dan sudut yaitu tidak adanya minat siswa terhadap pembelajaran matematika dan kebiasaan belajar yang buruk sehingga menimbulkan hasil yang tidak optimal. Adapun, faktor ekstern (luar diri sisiwa) kesulitan belajar siswa dalam mempelajari matematika pada materi garis dan sudut SMPN 4 Sindang dilihat melalui 2 aspek yaitu faktor lingkungan sekolah dan lingkungan keluarga (rumah). Dilihat dari faktor lingkungan sekolah, beberapa faktor yang dapat menyebabkan siswa berkesulitan belajar matematika pada garis dan sudut yaitu: (a) Waktu pembelajaran yang kurang efektif; (b) Media Pembelajaran; (c) metode pembelajaran yang monoton; (d) hubungan antar guru dengan siswa yang tergolong kurang harmonis; (e) hubungan antar siswa dengan siswa yang tergolong kurang harmonis; (f) Keaktifan siswa pada organisasi yang berlebihan. Adapun, dilihat dari faktor lingkungan keluarga. Beberapa faktor yang dapat menyebabkan siswa berkesulitan belajar matematika pada garis dan sudut yaitu: (a) Latar pendidikan orangtua yang rendah; (b) kurangnya perhatian orang tua terhadap kegiatan belajar anaknya dirumah; (c) keadaan ekonomi keluarga yang rendah; (d) suasana rumah yang ramai atau bahkan menyeramkan bagi siswa.

\section{DAFTAR PUSTAKA}

Ahmadi, A. (2009). Psikologi Sosial. Jakarta: Rineka Cipta.

Ahmadi, A \& Suprijono, W. (2013). Psikologi Belajar. Jakarta: Rineka Cipta.

Andini, R. A. (2015). Identifikasi Kesulitan Siswa Kelas VII SMP Negeri 1 Papar dalam Menyelesaikan Soal Aritmatika Sosial. Skripsi pada Universitas Nusantara PGRI Kediri: Tidak diterbitkan.

Cahyo, S.R. (2010). Faktor-Faktor yang Mempengaruhi Prestasi Belajar Kewirausahaan Siswa Kelas XI SMKN 1 Punggelan Banjanegara. Skripsi pada Universitas Negeri Semarang: Tidak diterbitkan.

Dasmo, dkk. (2012). Pengaruh Tingkat Pendidikan dan Pola Asuh Orang Tua Terhadap

Prestasi Belajar IPA. Jurnal Formatif 2(2): 132-139.

Djamarah, S. B. (2011). Psikologi Belajar. Jakarta: Rhineka Cipta.

Djamarah, S. B. dan Zain, A. (2002). Strategi Belajar Mengajar. Jakarta: Rineka Cipta. 
Dewantara, I. P. M. (2012). Identifikasi Faktor Penyebab Kesulitan BelajarKeterampilan Berbicara Siswa Kelas VII E SMPN 5 Negara dan Strategi Guru Untuk Mengatasinya. [Online] Tersedia: http://pasca.undiksha.ac.id/ejournal/index.php/jurnal_bahasa/article/viewFile/355/19 [17 November 2016]

Haryatni, A.P. (2014). Identifikasi Faktor-faktor Penyebab Kesulitan Belajar pada Siswa SMP Negeri 5 Kota Jambi. Skripsi pada Universitas Jambi: Tidak diterbitkan.

Emzir. (2014). Metodologi Penelitian Kualitatif Analisis Data. Jakarta: Raja Grafindo Persada.

Mulianto. (2011). Kesulitan Belajar (Learning Difficulty) Siswa SMA di Pedalaman Pариа. Tesis pada Universitas Kristen Satya Wacana Salatiga: Tidak diterbitkan.

Sakdiyah, S. (2011). Pengaruh Tingkat Pendidikan Orang Tua Terhadap Prestasi Belajar Anak Di sekolah (Studi Pada Kelas VIII di Madrasah Tsanawiyah Negeri Klego Kabupaten Boyolali Tahun 2011/2012. Skripsi pada Sekolah Tinggi Agama Islam Negeri Salatiga: Tidak diterbitkan.

Slameto. (2013). Dasar-Dasar Evaluasi Pendidikan. Jakarta: Rineka Cipta. 